\section{Facing the Facts}

\section{Beyond Chutzpah}

On the Misuse of Anti-Semitism and the Abuse of History NORMAN G. FINKELSTEIN

“A brave and daring challenge, meticulously researched. Must reading for anyone committed to a just and enduring peace in the Middle East."

-Amy Goodman, host of Democracy Now! $\$ 22.50$ cloth

\section{Myths about the Middle East}

FRED HALLIDAY

\section{Power Shift}

China and Asia's New Dynamics DAVID SHAMBAUGH, EDITOR

"This stimulating book is admirably suited for those seeking a better understanding of the underlying issues relating to China's expanding power."

-J. Stapelton Roy, former U.S. Ambassador to China, Indonesia, and Singapore $\$ 60.00$ cloth. $\$ 24.95$ paper

\section{Between Memory and Desire}

The Middle East in a Troubled Age

R. STEPHEN HUMPHREYS

Updated with a New Preface

"Humphreys's work is in the best tradition of writing on foreign cultures. Objective yet

sympathetic, scholarly yet accessible."

-New York Times Book Review
Halliday debunks one hundred of the most commonly misconstrued "facts" concerning the Middle East. In a straightforward and simple way that illuminates the issues without compromising their underlying complexities he gets to the core of each matter. $\$ 39.95$ cloth, \$12.95 paper

\section{Coffins on Our Shoulders}

The Experience of the Palestinian

Citizens of Israel

DAN RABINOWITZ AND

KHAWLA ABU-BAKER

"A fascinating work. Rabinowitz and AbuBaker succeed not only in challenging many basic assumptions and stereotypes about the victims of the Arab-Israeli conflict, but also in undermining much of the public discourse on the Palestinian minority inside Israel."

-Salim Tamari, Director, The Institute of Jerusalem Studies $\$ 50.00$ cloth, $\$ 19.95$ paper 


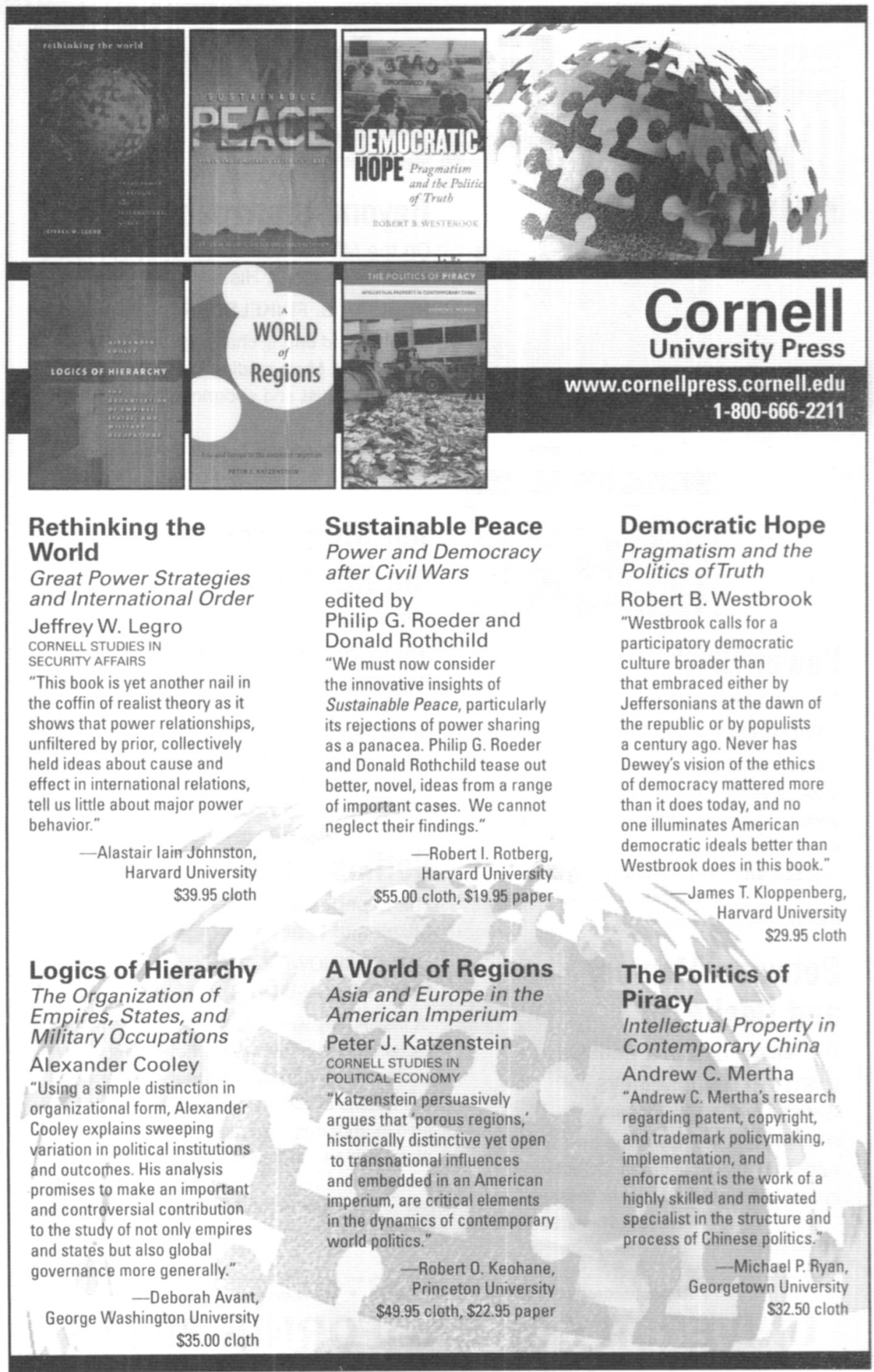




\section{WHAT'S NEW IN POLITICAL SCIENCE?}

\section{A Unified Theory of Party Competition \\ A Cross-National Analysis Integrating Spatial and Behavioral Factors}

James F. Adams, Samuel Merrill III, and Bernard Grofman

\$70.00: Hardback: 0-521-83644-1 \$28.99: Paperback: 0-521-54493-9

\section{The Atlantic Alliance Under Stress}

US-European Relations after Iraq Edited by David M. Andrews

\$75.00: Hardback: 0-521-84927-6 \$29.99: Paperback: 0-521-61408-2

\section{The Market for Force}

The Consequences of Privatizing Security Deborah D. Avant

\$75.00: Hardback: 0-521-85026-6 \$29.99: Paperback: 0-521-61535-6

\section{Beyond the Miracle of the}

\section{Market}

The Political Economy of Agrarian Development in Kenya Robert H. Bates

Political Economy of Institutions and Decisions

\$65.00: Hardback: 0-521-85269-2 \$22.99: Paperback: 0.521-61795-2

\section{Democracy Derailed in}

\section{Russia}

The Failure of Open Politics

\section{Steven Fish}

Cambridge Studies in

Comparative Politics

575.00: Hardback: 0-521-85361-3 529.99: Paperback: 0-521-61896-7

\section{The Neoconservative}

\section{Revolution}

Jewish Intellectuals and the Shaping of Public Policy

Murray Friedman \$29.00: Hardback: 0-521-83656-5

Prices subject to change.

\section{The Humanitarians}

The International Committee of the Red Cross

David P. Forsythe

\$75.00: Hardback: 0-521-84828-8

\$31.99: Paperback: 0-521-61281-0

\section{Modernization,}

Cultural Change, and

\section{Democracy}

The Human Development Sequence Ronald Inglehart and

Christian Welzel

\$75.00: Hardback: 0-521-84695-1

\$29.99: Paperback: 0-521-60971-2

\section{Capitalism, Democracy,} and Welfare

Torben Iversen

Cambridge Studies in

Comparative Politics

\$75.00: Hardback: 0-521-84861-X \$29.99: Paperback: 0-521-61307-8

\section{Poverty, Work and}

\section{Freedom}

Political Economy and the

Moral Order

David P. Levine and

S. Abu Turab Rizvi

\$65.00: Hardback: 0-521-84826-1

\section{Foundations of}

Comparative Politics

Ken Newton and

Jan W. Van Deth

Cambridge Textbooks in

Comparative Politics

575.00: Hardback: 0-521-82931-3

\$34.99: Paperback: 0-521-53620-0

\section{Decentralizing}

\section{the State}

Elections, Parties, and Local Power in the Andes

Kathleen O'Neill

\$70.00: Hardback: 0-521-84694-3 \$24.99: Paperback: 0-521-60970-4
Spatial Models of Parliamentary Voting Keith T. Poole

Analytical Methods for Social Research \$65.00: Hardback: 0-521-85194-7 \$24.99: Paperback: 0-521-61747-2

\section{The Right War?}

The Conservative Debate on Iraq Edited by Gary Rosen

\$65.00: Hardback: 0-521-85681-7 \$19.99: Paperback: 0-521-67318-6

\section{The Authoritarian Dynamic}

\section{Karen Stenner}

Cambridge Studies in Political Psychology and Public Opinion

\$75.00: Hardback: 0-521-82743-4 \$29.99: Paperback: 0.521-53478-X

\section{The New Transnational} Activism

Sidney Tarrow

Cambridge Studies in

Contentious Politics

\$55.00: Hardback: 0-521-85130-0 \$19.99: Paperback: 0-521-61677-8

\section{Trust and Rule}

Charles Tilly

Cambridge Studies in

Comparative Politics

\$55.00: Hardback: 0-521-85525-X \$19.99: Paperback: 0-521-67135-3

Federalism and the Market

Intergovernmental Conflict and Economic Reform in the

Developing World

Erik Wibbels

\$85.00: Hardback: 0-521-84381-2

Israel's Holocaust and the Politics of Nationhood Idith Zertal

Cambridge Middle East Studies \$30.00: Hardback: 0-521-85096-7 


\section{Pulitzer Prize-Winning Author}

"This book reminds us why tough, skeptical journalism matters so much: IT HELPS TO KEEP US FREE."

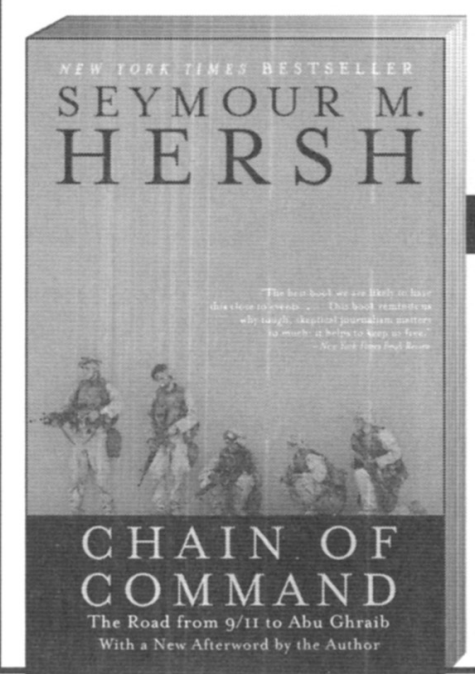

-New York Times Book Review

ISBN 0-06-095537-6 • 448pp • \$14.95 (\$19.95 Can.)

Also available as an e-book from PerfectBound

\section{NOW IN PAPERBACK}

"A searing indictment of George Bush and his closest political aides... authoritative and well-written."

-The Economist 


\section{New books from The MIT Press}

\section{Statehood and Security}

Georgia after the Rose Revolution edited by Bruno Coppieters and Robert Legvold

"The need for a comprehensive and up-todate analysis of the security challenges facing Georgia today is finally satisfied by this superb volume. It is hard to imagine a more timely contribution to this critical subject." - Gail W. Lapidus, Senior

Fellow, Stanford Institute for International Studies

American Academy Studies in Global Security 406 pp. \$24 paper

\section{Reassessing Security Cooperation in the Asia-Pacific}

Competition, Congruence, and Transformation edited by Amitav Acharya and Evelyn Goh Experts examine changing security arrangements in the Asia-Pacific region, particularly the rise of multilateral efforts at cooperative security.

BCSIA Studies in International Security 288 pp. \$25 paper

\section{Governing Water}

\section{Contentious Transnational Politics and} Global Institution Building Ken Conca

"This is an outstanding contribution to the study of international environmental politics and world politics more generally.

... the best treatment I know of the increasingly important international politics of water." - Margaret Keck, Johns Hopkins University

Global Environmental Accord: Strategies for Sustainabijity and Institutional innovation series 456 pp., 10 illus. $\$ 28$ paper

\section{Dealing with Dictators}

Dilemmas of U.S. Diplomacy

and Intelligence Analysis, 1945-1990

edited by Ernest R. May

and Philip D. Zelikow

Analysis of the foreign policy dilemmas U.S. leaders have faced in dealings with dictatorships in China, the Congo, Iran, Nicaragua, the Philippines, and Iraq before the Gulf War.

BCSIA Studies in International Security 400 pp. $\$ 27$ paper

\section{Electing to Fight}

Why Emerging Democracies Go to War Edward D. Mansfield and Jack Snyder

"American foreign policy has been based on the premise that democracy promotes peace. Electing to Fight conclusively shows, however, that democratization, when mishandled, leads to war. Its challenge to the conventional beliefs of scholars and politicians makes it one of the most important books on international affairs in recent decades."

- Samuel P. Huntington,

Harvard University

BCSIA Studies in International Security 288 pp. $\$ 32.95$

now in paperback

\section{Bare Branches}

The Security Implications of Asia's Surplus Male Population Valerie $M$. Hudson and Andrea M. den Boer

"An impressive and comprehensive account of sex ratios, especially in China, and may well give us reason to worry about that country's future and-in a globalized world-our own."

- James Q. Wilson,

The Wall Street Journal

400 pp. $\$ 17.95$ paper 


\section{WHAT'S NEW IN POLITICAL SCIENCE?}

\section{Economic Origins of Dictatorship and Democracy \\ Daron Acemoglu and James A. Robinson}

\$35.00: Hardback: 0-521-85526-8

\section{Immigration Phobia and} the Security Dilemma Russia, Europe, and the United States Mikhail A. Alexseev

\$70.00: Hardback: 0-521-84988-8

\section{Deadly Connections}

States that Sponsor Terrorism

Daniel Byman

\$30.00: Hardback: 0-521-83973-4

\section{Europe and the}

Recognition of New

States in Yugoslavia

Richard Caplan

\$75.00: Hardback: 0-521-82176-2

\section{Political Culture} and Institutional Development in Costa Rica and Nicaragua World-Making in the Tropics

Consuelo Cruz

\$80.00: Hardback: 0-521-84203-4

\section{Computational and} Mathematical Modeling in the Social Sciences

Scott de Marchi

\$65.00: Hardback: 0-521-85362-1 \$24.99: Paperback: 0-521-61913-0

\section{The Political Economy of} Terrorism

Walter Enders and Todd Sandler \$65.00: Hardback: 0-521-85100-9 \$23.99: Paperback: 0-521-61650-6

\section{The Far Enemy}

Why Jihad Went Global

Fawaz A. Gerges

\$27.00: Hardback: 0-521-79140-5

\section{Now in paperback!}

\section{Overcoming Intolerance in South Africa}

Experiments in Democratic Persuasion James L. Gibson and

Amanda Gouws

Cambridge Studies in Public Opinion and Political Psychology

\$27.99: Paperback: 0-521-67515-4

\section{Voting Radical Right in Western Europe}

Terri E. Givens

\$65.00: Hardback: 0-521-85134-3

\section{Al Qaeda Now}

Understanding Today's Terrorists

Edited by Karen J. Greenberg

\$60.00: Hardback: 0-521-85911-5 \$19.99: Paperback: 0-521-67627-4

Institutions and the Path to the Modern Economy Lessons from Medieval Trade

Avner Greif

Political Economy of Institutions and Decisions

\$80.00: Hardback: 0-521-48044-2 \$34.99: Paperback: 0-521-67134-5

\section{Why not Parties}

in Russia?

Democracy, Federalism, and the State

Henry E. Hale

\$75.00: Hardback: 0-521-84409-6

\section{Now in paperback!}

\section{America Alone}

The Neo-Conservatives and the Global Order

Stefan Halper and Jonathan Clarke

\$14.99: Paperback: 0-521-67460-3

\section{Congress and the}

\section{Cold War}

Robert David Johnson

\$70.00: Hardback: 0-521-82133-9 \$25.99: Paperback: 0-521-52885-2

\section{The American Era}

Power and Strategy for the 21st Century

Robert J. Lieber

\$28.00: Hardback: 0-521-85737-6

The Killing Trap

Genocide in the Twentieth Century

Manus I. Midlarsky

\$75.00: Hardback: 0-521-81545-2 \$28.99: Paperback: 0-521-89469-7

\section{Radical Right}

Voters and Parties in the Electoral Market

\section{Pippa Norris}

\$70.00: Hardback: 0-521-84914-4 \$24.99: Paperback: 0-521-61385-X

Machiavelli's Liberal Republican Legacy

Edited by Paul A. Rahe

\$75.00: Hardback: 0-521-85187-4

Racial Politics in Post-Revolutionary Cuba Mark Q. Sawyer

\$60.00: Hardback: 0-521-84807-5

Democracy without

Competition in Japan

Opposition Failure in a One-Party Dominant State

Ethan Scheiner

\$70.00: Hardback: 0-521-84692-7 \$25.99: Paperback: 0.521-60969-0

The Blair Effect 2001-5 Edited by Anthony Seldon and Dennis Kavanagh

\$70.00: Hardback: 0-521-86142-X \$27.99: Paperback: 0-521-67860-9

From Movements to Parties in Latin America The Evolution of Ethnic Politics Donna Lee Van Cott \$75.00: Hardback: 0-521-85502-0 Prices subject to change 


\section{Political Spaces}

\section{Matthew Sparke}

\section{In the Space of Theory}

Postfoundational Geographies of the Nation-State

Engaged with theory and grounded in close study of cultural, political, and economic change, In the Space of Theory explores the geographies of struggle that at once underlie and undermine the hyphen in contemporary nation-states. $\$ 25.95$ paper $\bullet \$ 77.95$ cloth $\bullet 416$ pages $\bullet$ Borderlines Series, volume 26
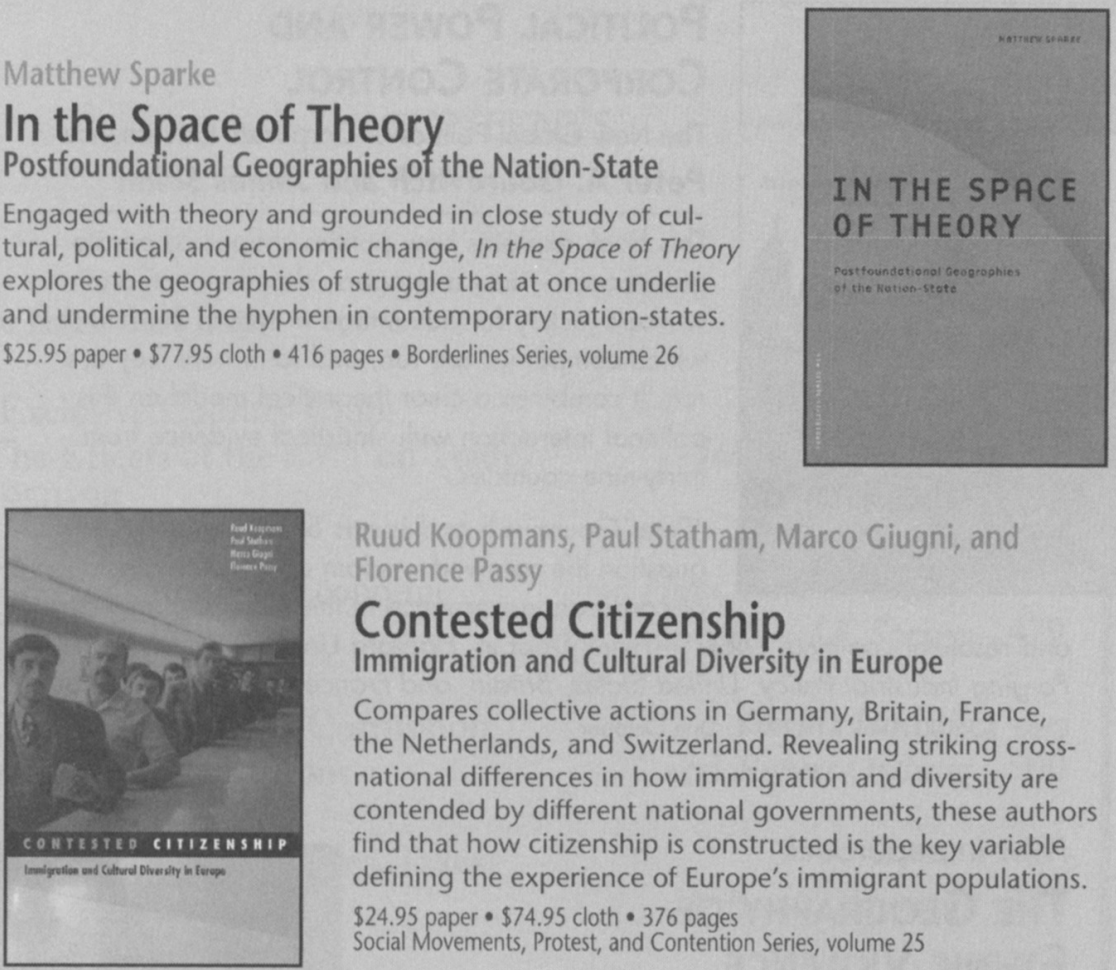

\section{Ruud Koopmans, Paul Statham, Marco Giugni, and} Florence Passy

\section{Contested Citizenship} Immigration and Cultural Diversity in Europe

Compares collective actions in Germany, Britain, France, the Netherlands, and Switzerland. Revealing striking crossnational differences in how immigration and diversity are contended by different national governments, these authors find that how citizenship is constructed is the key variable defining the experience of Europe's immigrant populations. $\$ 24.95$ paper $\bullet \$ 74.95$ cloth $\bullet 376$ pages Social Movements, Protest, and Contention Series, volume 25

\section{Himadeep Muppidi}

\section{The Politics of the Global}

Refusing the false choice between objectivity and subjectivity, Himadeep Muppidi considers the production of the global as an intersubjective process that reveals the different political possibilities opened by global relays of meanings, identity, and power. Muppidi concludes by exploring a variety of spaces and strategies for resisting the colonization of the global. $\$ 19.95$ paper $\bullet \$ 59.95$ cloth $\bullet 192$ pages $\bullet$ Borderlines Series, volume 23

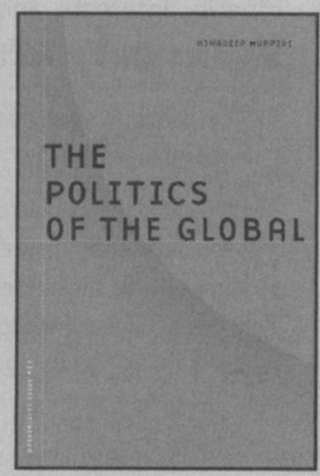

\section{University of Minnesota Press www.upress.umn.edu $\quad$ 773-702-7000}




\section{Discerning}

\section{Political Power and CorPorate CONTROL}

Political Power \& rus new Gooke

Corporate Control conposeref Goverenumce

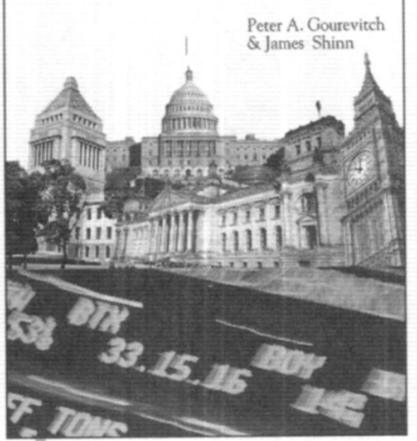

The New Global Politics of Corporate Governance

\section{Peter A. Gourevitch and James Shinn}

This book explains how politics shapes corporate governance-how managers, shareholders, and workers jockey for advantage in setting the rules by which companies are run, and for whom they are run. It combines a clear theoretical model on this political interaction with statistical evidence from thirty-nine countries.

"Peter Gourevitch and James Shinn brilliantly question the received wisdom about state regulation of corporate governance in this resolutely empirical

and resolutely political book." - Frank Dobbin, Harvard University, author of Forging Industrial Policy: United States, Britain, and France in the Railway Age Cloth $\$ 35.00$ 0-691-12291-1 Due October

New in paperback

\section{THE GeOgRaphy OF ETHNIC VIOLENCE}

Identity, Interests, and the Indivisibility of Territory

\section{Monica Duffy Toft}

"Toft's book is well written and closely argued."

-Foreign Affairs

"Toft proposes a useful theory and adduces convincing evidence on some of the key determinants of severe ethnic violence." - Stuart J. Kaufman,

Perspectives on Politics

Paper \$18.95 0-691-12383-7 Due November

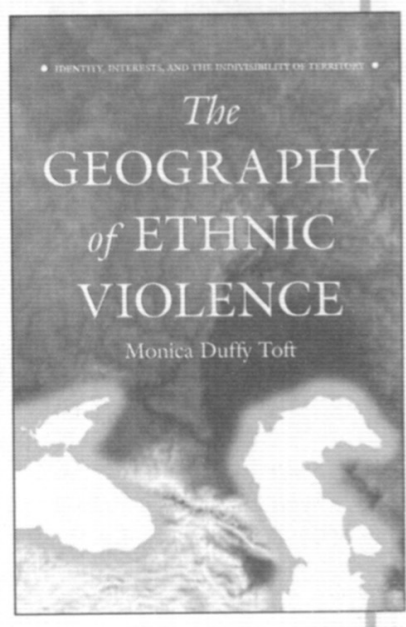

Celebrating 100 Years of Excellence 